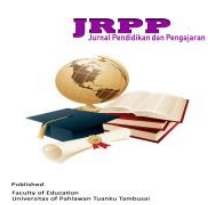

Jurnal Review Pendidikan dan Pengajaran

http://journal.universitaspahlawan.ac.id/index.php/jrpp

Volume 3 Nomor 2, Desember 2020

P-2655-710X e-ISSN 2655-6022
Submitted : $\quad 26 / 10 / 2020$

Reviewed: $28 / 10 / 2020$

Accepted: 10/11/2020

Published: $03 / 12 / 2020$
Melani Anugrah ${ }^{1}$ Hukmi $^{2}$

Febrialismanto $^{3}$

\section{PERBEDAAN PENGETAHUAN SAINS ANTARA ANAK LAKI-LAKI DAN PEREMPUAN USIA 5-6 TAHUN DI TK KECAMATAN MARPOYAN DAMAI KOTA PEKANBARU}

\begin{abstract}
Abstrak
Penelitian ini bertujuan untuk melihat perbedaan pengetahuan sains antara anak laki-laki dan perempuan usia 5-6 tahun di TK Kecamatan Marpoyan Damai Kota Pekanbaru. Penelitian ini menggunakan penelitian kuantitatif dengan jenis penelitian komparatif. Populasi dalam penelitian ini adalah anak usia 5-6 tahun di TK Kecamatan Marpoyan Damai Kota Pekanbaru dilakukan di 6 lembaga TK yaitu TK Shandy Putra Telkom, TK Muhajadah, TK Ibadah, TK Lawiyah, TK Al-Khairat dan TK Inayah berjumlah 158 orang anak yang terdiri dari 81 anak laki-laki dan 77 anak perempuan. Analisis data dilakukan dengan Korelasi Product Moment. Hasil penelitian menjelaskan bahwa Pengetahuan sains anak laki-laki usia 5-6 tahun di TK Kecamatan Marpoyan Damai Kota Pekanbaru berada pada kategori berkembang sesuai harapan (BSH) dengan rata-rata pengetahuan sains yaitu 60,03, Pengetahuan sains anak perempuan usia 5-6 tahun di TK Kecamatan Marpoyan Damai Kota Pekanbaru berada pada kategori berkembang sangat baik (BSB) dengan rata-rata pengetahuan sains yaitu 65,57dan terdapat perbedaan pengetahuan sains antara anak laki-laki dan perempuan usia 5-6 tahun di TK Kecamatan Marpoyan Damai Kota Pekanbaru. Pengetahuan sains anak perempuan lebih baik dari pengetahuan sains anak laki-laki.
\end{abstract}

Kata Kunci: Perbedaan Pengetahuan Sains, Anak Laki-laki dan Perempuan, Usia 5-6 Tahun

\begin{abstract}
This study aims to see the differences in scientific knowledge between boys and girls aged 5-6 years in Kindergarten, Marpoyan Damai District, Pekanbaru City. This research uses quantitative research with comparative research type. The population in this study were children aged 5-6 yearsKindergarten in Marpoyan Damai District, Pekanbaru City was conducted in 6 kindergartens, namely TK Shandy Putra Telkom, TK Muhajadah, TK Ibadah, TK Lawiyah, TK Al-Khairat and TK Inayah totaling 158 children consisting of 81 boys and 77 girls. Data analysis was performed with Product Moment Correlation. The results of the study explain thatScience knowledge of boys aged 5-6 years in Kindergarten, Marpoyan Damai District, Pekanbaru City is in the category of developing according to expectations $(\mathrm{BSH})$ with an average science knowledge of 60.03, Science knowledge of girls aged 5-6 years in District Kindergarten Marpoyan Damai Pekanbaru City is in the very well developed category (BSB) with an average scientific knowledge of 65.57 and there are differences in scientific knowledge between boys and girls aged 5-6 years in Kindergarten, Marpoyan Damai District, Pekanbaru City. Girls 'science knowledge is better than boys' science knowledge.
\end{abstract}

Keywords: Measuring Pool Media, Early Childhood Measuremen

1,2,3) Program Studi Pendidikan Guru Pendidikan Anak Usia Dini, Fakultas Keguruan dan Ilmu Pendidikan, Universitas Riau

${ }^{1)}$ Alamat email Melanianugrah5@gmail.com 


\section{PENDAHULUAN}

Pendidikan Anak Usia Dini (PAUD) sebagai pendidikan yang diselenggarakan sebelum pendidikan dasar. Pendidikan yang diberikan pada usia dini sebaiknya disesuaikan dengan usia perkembangannya. Dalam proses pembelajaran keterbaharuan pengetahuan yang diberikan kepada peserta didik sangat diperlukan hal ini dikarenakan supaya anak didik mendapatkan pengetahuan yang baru supaya nantinya dapat menjadi persiapan peserta didik mempersiapkan diri untuk menghadapai tantangan pada masa yang akan datang. (Febrialismanto \& Hidayatun, 2019).

Salah satu pengetahuan yang dapat mengembangkan kemampuan kognitif anak adalah pengetahuan sains. Pengetahuan sains memiliki peranan penting dalam peningkatan mutu pendidikan, khususnya di dalam menghasilkan peserta didik yang berkualitas yaitu manusia yang mampu berpikir kritis, kreatif, dan logis. Sains bagi anak usia dini bukanlah hanya sekedar kumpulan fakta, melainkan melibatkan aktivitas mengobservasi tentang apa yang terjadi, mengklasifikasikan atau mengorganisasikan informasi, memprediksi tentang apa yang akan terjadi, menguji prediksi melalui kegiatan terbimbing serta merumuskan kesimpulan (Suci, 2019). Kemampuan memahami pemahaman anak dalam pembelajaran sangat penting bagi guru PAUD (Febrialismanto \& Ria, 2020).

Anak-anak memiliki otak layaknya spons, dengan mudah menyerap berbagai ilmu pengetahuan yang diajarkan. Begitu pula dengan pendidikan sains dan teknologi yang tidak diajarkan di sekolah saja, tetapi juga melalui tayangan film atau telivisi. Orang tua yang memiliki anak perempuan dan laki-laki mungkin menyadari perkembangan anak perempuan dan laki-laki sangat berbeda. Perbedaan struktur otak, kimia tubuh, dan hormon pada anak laki-laki dan perempuan, yang sangat mempengaruhi perbedaan di antara mereka (Jerry dan Barbara, 2012).

Hal ini membuat ilmuwan percaya perbedaan ukuran otak ini membuat kecerdasan, perilaku dan karakter juga berbeda. Otak anak laki-laki dan perempuan yang memiliki usia yang sama berada dalam tahap perkembangan otak keduanya bisa saja saling mengejar satu sama lain.Berdasarkan jurnal Nature Communication, para peneliti melakukan pengujian terhadap 1,6 juta partisipan yang terdiri dari anak prasekolah sampai mahasiswa perguruan tinggi untuk mencari tau siapa yang paling cerdas anak laki-laki atau perempuan.

Pembelajaran sains pada pendidikan anak usia dini memberikan manfaat yang sangat besar untuk berbagai aspek perkembangan anak, sehingga para peneliti menekankan betapa pentingnya pembelajaran sains yang di mulai sejak dini (Trundle, 2005). Pembelajaran sains bagi anak usia dini mengembangkan pemahaman serta pengetahuan suatu konsep sains, mengembangkan kemampuan berpikir, menanamkan sikap positif, dan memberikan landasan yang kuat untuk pengembangan konsep sains dipendidikan selanjutnya (Trundle, 2005).

Penelitian ini bertujuan untuk mengetahui pengetahuan sains anak laki-laki usia 5-6 tahun di TK Kecamatan Marpoyan Damai Kota Pekanbaru, untuk mengetahui pengetahuan sains anak perempuan usia 5-6 tahun di TK Kecamatan Marpoyan Damai Kota Pekanbaru dan untuk membandingkan perbedaan perbedaan pengetahuan sains antara anak laki-laki dan perempuan usia 5-6 tahun di TK Kecamatan Marpoyan Damai Kota Pekanbaru.

\section{METODE}

Dalam penelitian ini menggunakan pendekatan kuantitaif dengan jenis penelitian komparatif. Penelitian ini dilakukan untuk melihat perbedaan pengetahuan sains antara anak laki-laki dan perempuan usia 5-6 tahun di TK Kecamatan Marpoyan Damai Kota Pekanbaru. Desain di dalam penelitian ini menggunakan desain komparatif dimana peneliti membandingkan dua kelompok berbeda.

Kelompok yang dibandingkan adalak kelompok anak laki-laki dan perempuan usia 5-6 tahun. Peneliti membandingkan perbedaan pengetahuan sains antara anak laki-laki dan perempuan usia 5-6. Populasi dalam penelitian ini adalah anak usia 5-6 tahun di TK Kecamatan Marpoyan Damai Kota Pekanbaru dilakukan di 6 lembaga TK yaitu TK Shandy Putra Telkom, TK Muhajadah, TK Ibadah, TK Lawiyah, TK Al-Khairat dan TK Inayah berjumlah 158 orang anak yang terdiri dari 81 anak laki-laki dan 77 anak perempuan.Teknik pengambilan sampel ini 
peneliti menggunakan sampel secara acak (Random Sampling) dengan rumus Taro Yamane dan Slovin (Riduan dan Akdon, 2009).

Penelitian ini menggunakan jenis penelitian komparatif sejenis penelitian deskriptif yang ingin mencari jawaban secara mendasar tentang sebab-akibat, dengan menganalisis faktor-faktor penyebab terjadinya ataupun munculnya suatu fenomena tertentu.Jadi penelitian komparatif adalah jenis penelitian yang digunakan untuk membandingkan antara dua kelompok atau lebih dari suatu variabel tertentu.Variabel - variabel dalam penelitian ini adalah sebagai berikut:

Variabel $\mathrm{X}_{1} \quad$ :Anak laki-laki

Variabel $\mathrm{X}_{2} \quad$ :Anak perempuan

Variabel Y: Pengetahuan Sains

Teknik pengumpulan data dalam penelitian ini dilakukan dengan observasi. Observasi digunakan untuk mengumpulkan data pengetahuan sains pada anak usia 5-6 tahun antara anak laki-laki dan perempuan di TK Kecamatan Marpoyan Damai. Teknik analisis data menggunakan uji validitas, uji reliabilitas dan uji hipotesis.

\section{HASIL DAN PEMBAHASAN}

Data dalam penelitian ini berbentuk observasi dengan menggunakan lembar kerja anak (LKA) pada bulan Agustus 2020 kepada anak usia 5-6 tahun sebanyak 61 sesuai dengan sampel yang telah ditetapkan baik yang laki-laki maupun yang perempuan di TK Kecamatan Marpoyan Damai Kota Pekanbaru. Adapun lembar observasi yang meliputi 4 aspek yaitu 1) Physical Science (Ilmu Fisika) yang terdiri dari tujuh sub indikator ; 2) Health Science (Ilmu Kesehatan) yang terdiri 3 sub indikator; 3) Life Science (Ilmu Kehidupan) yang terdiri dari 5 sub indikator; 4) Earth And Space Science (Ilmu Bumi dan Luar Angkasa) yang terdiri dari 5 sub indikator. Dari 61 lembar observasi yang telah dikerjakan, semuanya dianggap layak dijadikan sebagai data penelitian. Setelah data terkumpul dianalisis dengan $T$ test, digunakan untuk mengetahui apakah ada perbedaan pengetahuan sains antara anak laki-laki dan perempuan. Responden terdiri dari anak laki-laki dan perempuan usia 5-6 Tahun. Jumlah seluruh responden ada 61 anak yang meliputi 31 anak laki-laki dan 30 anak perempuan usia 5-6 tahun.

Tabel 1. Hasil Uji Validitas Instrument Observasi Yang Terdiridari Empat Aspek :

\begin{tabular}{|l|l|l|l|}
\hline Item & $\begin{array}{c}\text { Cronbach Alpha if Item } \\
\text { Deleted (Harga rhitung }\end{array}$ & Harga rtabel & Hasil \\
\hline 1 & 0,507 & 0,254 & \\
\hline 2 & 0,369 & 0,254 & VALID \\
\hline 3 & 0,689 & 0,254 & VALID \\
\hline 4 & 0,725 & 0,254 & VALID \\
\hline 5 & 0,606 & 0,254 & VALID \\
\hline 6 & 0,642 & 0,254 & VALID \\
\hline 7 & 0,671 & 0,254 & VALID \\
\hline 8 & 0,374 & 0,254 & VALID \\
\hline 9 & 0,257 & 0,254 & VALID \\
\hline 10 & 0,305 & 0,254 & VALID \\
\hline 11 & 0,384 & 0,254 & VALID \\
\hline 12 & 0,402 & 0,254 & VALID \\
\hline 13 & 0,551 & 0,254 & VALID \\
\hline 14 & 0,561 & 0,254 & VALID \\
\hline 15 & 0,530 & 0,254 & VALID \\
\hline 16 & 0,428 & 0,254 & VALID \\
\hline
\end{tabular}




\begin{tabular}{|l|l|l|l|}
\hline 17 & 0,419 & 0,254 & VALID \\
\hline 18 & 0,513 & 0,254 & VALID \\
\hline 19 & 0,381 & 0,254 & VALID \\
\hline 20 & 0,402 & 0,254 & VALID \\
\hline
\end{tabular}

Tabel di atas menunjukkan bahwa semua soal objektif tes memiliki $\mathrm{r}$ hitung $>\mathrm{r}$ tabel. Dengan demikian semua aspek instrumen observasi tersebut dapat dinyatakan valid. Tabel di atas menunjukkan bahwa nilai Cronbach's Alpha dari instrumen observasi > dari 0,7, maka pernyataan tersebut dinyatakan reliabel.

Tabel 2. Hasil Perhitungan Reliabilitas

\begin{tabular}{llll}
\hline Instrumen & Cronbach's Alpha & N of Items & Hasil \\
\hline Observasi & 0,835 & 20 & Reliabel \\
\hline
\end{tabular}

Berikut ini perbandingan pengetahuan sains anak laki-laki dan perempuan usia 5-6 tahun di TK Kecamatan Marpoyan Damai Kota Pekanbaru

Tabel 3. Perbandingan Total Skor

\begin{tabular}{llllll}
\hline \multirow{2}{*}{ Kelompok } & N & Mean & $\begin{array}{l}\text { Std. } \\
\text { Deviation }\end{array}$ & $\begin{array}{l}\text { Std. } \\
\text { Mean }\end{array}$ \\
\hline \multirow{2}{*}{ Skor } & Anak Laki-laki & 31 & 60,03 & 6,780 & 1,218 \\
\cline { 2 - 6 } & Anak Perempuan & 30 & 65,57 & 4,725 & 4,725 \\
\hline
\end{tabular}

Sumber : Olahan Data Penelitian 2020

Rata-rata skor total pengetahuan sains antara anak laki-laki usia 5-6 tahun di TK Kecamatan Marpoyan Damai Kota Pekanbaru sebesar 60,03 sedangkan rata-rata skor total pengetahuan sains anak perempuan usia 5-6 tahun di TK Kecamatan Marpoyan Damai sebesar 65,57 .

Skor total rata-rata total pengetahuan sains anak perempuan usia 5-6 tahun di TK Kecamatan Marpoyan Damai lebih tinggi dibanding rata-rata skor total pengetahuan sains antara anak laki-laki usia 5-6 tahun di TK Kecamatan Marpoyan Damai Kota Pekanbaru. Jika dilihat dari dari hasil analisis deskriptif dapat dilihat bahwa antara anak laki-laki dan anak perempuan terdapat perbedaan nilai rata-rata kedua sampel tersebut. Untuk lebih memperjelas perbedaan antara kedua sampel tersebut apakah perbedaan keduanya signifikan atau tidak maka perlu dilakukan uji yang kedua yaitu uji statistik inferensial dimana uji statistik inferensial dalam penelitian ini dilakukan terlebih dahulu uji normalitas dan homogenitas.

\section{Analisi Data}

\section{a. Uji Nomalitas}

Uji normalitas dilakukan untuk menentukan apakah sebaran data berdistribusi normal atau tidak. Penelitian menggunakan uji normalitas dengan cara Kolmogrof (uji K-S sample) pada SPSS 23. Hasil dari uji normalitas dapat dilihat dari tabel berikut: 


\section{Tabel 4 Uji Normalitas}

Tests of Normality

\begin{tabular}{|ll|l|l|l|}
\hline \multirow{2}{*}{ Jenis_kelamin } & \multicolumn{3}{|l|}{ Kolmogorov-Smirnov } \\
\cline { 3 - 5 } & Statistic & df & Sig. \\
\hline Hasil & Laki-laki &, 135 & 31 &, 162 \\
& perempuan &, 158 & 30 &, 054 \\
\hline
\end{tabular}

Lilliefors Significance Correction

Data dikatakan normal jika tingkat Sig. Pada Kolmogrov-Smirnov lebih besar dari 0,05 maka data didistribusikan normal, jika kurang dari 0,05 maka data didistribusikan tidak normal. Nilai Sig. Anak berjenis kelamin laki-laki 0,162 dan nilai Sig. Anak berjenis kelamin perempuan sebesar 0,54. Nilai tersebut menunjukkan bahwa Sig.>0,05 maka Ho diterima, data tersebut berdistribusi normal.

\section{b. Uji Homogen}

Pengujian homogenitas dimaksudkan untuk memberikan keyakinan bahwa sekumpulan data yang dimanipulasi dalam serangkaian analisis memang berasal dari populasi yang tidak jauh berbeda keragamannya. Analisis homogenitas dalam pengujian ini menggunakan uji one-way anova dengan bantuan program SPSS versi 23. Kolom yang dilihat pada print out ialah kolom Sig. Jika nilai pada kolom Sig.>0,05 maka Ho diterima.

\section{Tabel 5. Uji Homogenitas}

\section{Test of Homogeneity of Variances}

\begin{tabular}{|l|l|l|l|}
\hline Levene Statistic & df1 & df2 & Sig. \\
\hline 2,103 & 1 & 59 &, 152 \\
\hline
\end{tabular}

Sumber : Olahan Data Penelitian 2020

Dari hasil pengolahan data yang tertera diatas maka diperoleh Sig yaitu 0,152. Untuk itu dapat dikatakan bahwa Ho diterima karena sig 0,152>0,05, untuk itu disimpulkan bahwa varians pengetahuan sains anak laki-laki usia 5-6 tahun dan pengetahuan sains anak perempuan usia 5-6 tahun adalah sama atau dikatakan homogen.

\section{c. Uji Hipotesis}

Berdasarkan uji normalitas maupun uji homogenitas yang telah dilakukan maka statistik yang digunakan dalam pengujian hipotesis dalam penelitian ini adalah statistik parametrik dengan uji t-tes sampel independen. Uji ini dilakukan pada pengetahuan sains anak laki-laki usia 5-6 tahun dan pengetahuan sains anak perempuan usia 5-6 tahun di TK Kecamatan Marpoyan Damai Kota Pekanbaru. Pengetahuan sains dua kelompok anak dikatakan berbeda secara signifikan jika Sig. <0,05. Jika Sig. $<0,05$ maka Ho ditolak, Ha diterima.

Tabel 6. Uji Hipotesis 


\section{Independent Samples Test}

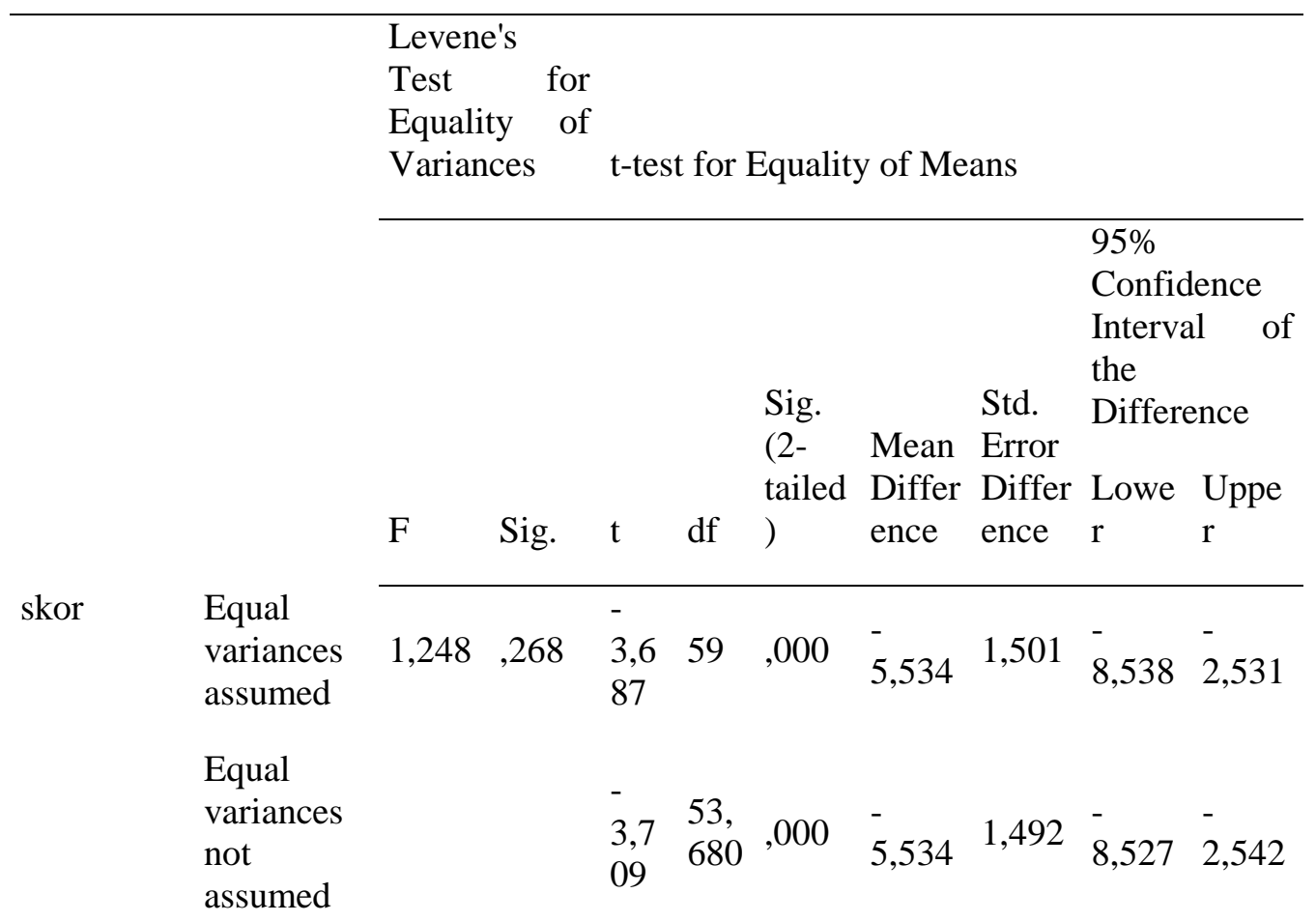

Sumber : Olahan Data Penelitian 2020

Berdasarkan hasil pengolahan data dengan bantuan program SPSS versi 23 menggunakan uji Independent samples test, maka diperoleh $\mathrm{Sig}=0,000$. Dapat disimpulkan bahwa Ho di tolak karena 0,000 $<0,05$. Dengan demikian kesimpulan akhir dari penelitian atau hipotesis yang diterima adalah memiliki perbedaam pengetahuan sains anak laki-laki dan pengetahuan sains anak perempuan di TK Kecamatan Marpoyan Damai Kota Pekanbaru.

\section{Pembahasan Hasil Penelitian}

Penelitian ini bertujuan untuk mengetahui apakah ada perbedaan pengetahuan sains antara anak laki-laki dan perempuan usia 5-6 tahun di TK Kecamatan Marpoyan Damai Kota Pekanbaru. Penelitian ini dilakukan pada 31 anak laki-laki dan 30 anak perempuan usia 5-6 tahun. Teknik pengumpulan data dalam penelitian ini dilakukan dengan observasi menggunakan lembar kerja anak (LKA). Item test pengetahuan sains anak usia 5-6 tahun yang digunakan yaitu 20 item dengan skor BB (1), MB (2), BSH (3), BSB (4).

Sains merupakan cara kita berpikir dan melihat dunia sekitar kita. Ini adalah salah satu cabang ilmu atau subjek bahasan yang mengkaji fakta-fakta/kenyataan yang terkait dengan fenomena alam. Jadi sains dapat disimpulkan adalah semua yang ada/nampak di sekitar kita, terjadi di mana kita berada.Pembelajaran sains pada anak-anak usia dini dapat diartikan sebagai hal-hal yang menstimulus mereka untuk meningkatkan rasa ingin tahu, minat dan pemecahan masalah, sehingga memunculkan pemikiran dan perbuatan seperti mengobservasi, berpikir, dan mengaitkan antar konsep atau peristiwa (Brewer, 2007). Dari item tersebut rata-rata anak berkembang sesuai harapan dimana pada tujuan pendidikan sains sejalan dengan kurikulum sekolah, yakni mengembangkan anak secara utuh baik aspek domain kognitif, aspek afektif maupun aspek psikomotor anak. Sedangkan Menurut Leeper (dalam Nughara, 2005) tujuan sains yang mendasar adalah untuk memupuk pemahaman, minat dan penghargaan anak didik terhadap dunia di mana dia hidup agar anak memiliki sikap-sikap ilmiah.

Setelah hasil observasi pengetahuan sains antara anak laki-laki dan perempuan usia 5-6 tahun di TK Kecamatan Marpoyan Damai Kota Pekanbaru diperoleh dan kemudian dianalisis dengan menggunakan statistik parametrik dengan uji t-tes sampel independen, maka diperoleh 
Sig=0,000. Dapat disimpulkan bahwa Ho di tolak karena $0,000<0,05$. Penelitian atau hipotesis yang diterima dinyatakan memiliki perbedaan pengetahuan sains antara anak laki-laki dan perempuan usia 5-6 tahun. Selain itu perbedaan juga ditunjukkan dengan nilai mean yang menujukkan laki-laki 60,03 dan perempuan 65,57, dimana rata-rata kelompok laki-laki lebih rendah dibanding kelompok perempuan. Hal tersebut semakin memperkuat hipotesis bahwa adanya perbedaan pengetahuan sains antara anak laki-laki dan perempuan usia 5-6 tahun di TK Kecamatan Marpoyan Damai Kota Pekanbaru.

Adapun penelitian yang sejalan dengan penelitian perbedaan kemampuan antara anak laki-laki dan perempuan usia 5-6 tahun dilakukan oleh(Ali \& Yuniarni, 2016) yang berjudul “ Kemampuan Berhitung Berdasarkan Gender Pada Anak Usia 5-6 Tahun di TK Mujahidin 1 Pontianak". Hasil dari penelitian ini adalah Hasil analisis data menunjukkan kemampuan berhitung anak laki dengan hasil presentase $45,23 \%$ kategori sedang berkembang sesuai harapan sedangkan kemampuan berhitung anak perempuan dengan hasil presentase 45,23\% kategori sedang berkembang sangat baik.

Selanjutnya hasil penelitian yang sejalan juga dilakukan oleh (Afriana, Permanasari, \& Fitriani, 2016) dengan judul " Penerapan project based learning terintegrasi STEAM untuk meningkatkan literasi sains ditinjau dari gender. Penelitian ini diperoleh hasil sebesar sig. $=\mathrm{p}$ value $/ 2=0,024 / 2=0,012$. Sig. $0,012<(\alpha) 0,05$. maka H1 diterima, berarti terdapat perbedaan signifikan antara kelas lakilaki dan kelas perempuan. Dengan demikian dapat disimpulkan bahwa Literasi sains siswa kelas laki-laki dan kelas perempuan sama-sama mengalami peningkatan dengan rerata N_Gain berturut-turut 0,36 dan 0,31 (dalam kategori sedang) untuk aspek pengetahuan, dan kompetensi. Peningkatan aspek sikap sains padakelas perempuan lebih tinggi dibandingkan dengan kelas laki-laki.

Penelitian sejalan lainnya dilakukan oleh (Pamuji \& Sodikin, 2020) dengan judul “ Hubungan jenis kelamin, usia, dan urutan kelahiran dengan kemampuan mengkombinasikan warna menggunakan media finger painting". Hasil dari penelitian ini adala Kemampuan responden dalam mengkombinasikan warna pada variabel jenis kelamin terdapat 11 responden perempuan yang mampu mengkombinasikan 3 warna dan 1 responden laki-laki yang mampu mengkombinasikan 3 warna. Hasil analisis yang diperoleh yaitu terdapat hubungan antara karakteristik anak dengan kemampuan mengkombinasikan warna menggunakan media finger painting anak usia prasekolah pada variabel jenis kelamin didapatkan nilai chi square sebesar 6.767 dan nilai $\mathrm{p}$ sebesar 0.034 . Nilai p sebesar 0.034 menunjukkan bahwa ada hubungan yang signifikan ( $\mathrm{p}$ value $<0.05$ ).

Penelitian yang menunjukkan adanya perbedaan antara laki-laki dan perempuan telah dilakukan Aziz \& Mangestuti (2006) pada 304 mahasiswa yang menemukan bahwa perempuan lebih tinggi dibanding laki-laki dalam hal tingkat kecerdasan intelektual yang diukur dengan tes Standard Progressive Matrices (SPM) dengan perbandingan mean 127,28:166,80, untuk kecerdasan emosional 88,69:90,93, dan untuk kecerdasan spiritual 78,20:81,30.

Perbedaan Gender Terhadap Kemampuan Berhitung Matematika Menggunakan Otak Kanan Pada Siswa Kelas I yang dilakukan oleh (Kristi Liani, 2013) menyebutkan bahwa siswa perempuan mendapatkan kenaikan nilai yang lebih tinggi dibandingkan dengan siswa laki-laki dengan perbedaan nilai sebesar 16 poin untuk siswa perempuan dan 11 poin untuk siswa lakilaki. Terlihat perbedaan kemampuan anak laki-laki dan perempuan saat pembelajaran berlangsung.

Hal ini juga didukung oleh hasil penelitian sebelumnya yaitu penelitian yang dilakukan (Barnas \& Ridwan, 2019) Perbedaan Gender dalam Pengetahuan, Sikap dan Perilaku Mahasiswa Pendidikan Fisika. Bentuk yang dilakukan pada penelitian ini menggunakan metode deskriptif yang sifatnya kausal komparatif. Metode pengumpulan data dengan tes, kuisoner dan wawancara. Sebelum diberi perlakuan terlebih dahulu dilakukan uji normalitas, uji kesamaan dua varian, dan uji keseimbangan. Hasil penelitian menunjukan bahwa mahasiswa perempuan lebih baik dalam hal pengetahuan dibandingkan dengan mahasiswa laki-laki, hal tersebut dapat dilihat dari rata-rata yang diperoleh tingkat pengetahuan mahasiswa laki-laki yaitu 19,11 dan mahasiswa perempuan sebesar 20,30. Pengolahan data untuk variabel tingkat pengetahuan menggunakan dummy variabel dengan alasan supaya keseluruhan jenis data menjadi sejenis. Dari hasil analisis diperoleh untuk $\alpha=5 \%$ diperoleh bahwa thitung $=2,256>$ t0,95(84) $=$ 
2,378, maka $\mathrm{H} 0$ ditolak dan $\mathrm{H} 1$ diterima. Artinya terdapat perbedaan antara tingkat pengetahuan Mahasiswa laki-laki dan perempuan dalam pemeliharaan kebersihan lingkungan Kampus di Program Studi Pendidikan Fisika.

Berdasarkan dari penelitian terdapat beberapa kesamaan yaitu sama sama membahas perbedaan berdasarkan jenis kelamin, yang mana terdapat kesamaan hasil penelitian yaitu terdapat perbedaan antara jenis kelamin anak perempuan dengan anak laki-laki. Jenis kelamin anak perempuan mendapatkan skor lebih tinggi dibandingkan dengan skor jenis kelamin anak laki-laki. Perbedaan dari masing-masing penelitian adalah variabel yang hendak dibandingkan. Maka dari itu dapat disimpulkan bahwa terdapat perbedaan pengetahuan sains anak laki-laki dengan anak perempuan di tk kecamatan marpoyan damai kota pekanbaru.

\section{SIMPULAN}

Adapun kesimpulan yang dapat diuraikan peneliti ialah pengetahuan sains anak laki-laki usia 5-6 tahun di TK Kecamatan Marpoyan Damai Kota Pekanbaru berada pada kategori berkembang sesuai harapan (BSH) dengan rata-rata pengetahuan sains yaitu 60,03. Pengetahuan sains anak perempuan usia 5-6 tahun di TK Kecamatan Marpoyan Damai Kota Pekanbaru berada pada kategori berkembang sangat baik (BSB) dengan rata-rata pengetahuan sains yaitu 65,57. Terdapat perbedaan pengetahuan sains antara anak laki-laki dan perempuan usia 5-6 tahun di TK Kecamatan Marpoyan Damai Kota Pekanbaru. Pengetahuan sains anak perempuan lebih baik dari pengetahuan sains anak laki-laki.

\section{DAFTAR PUSTAKA}

Afriana, J., Permanasari, A., \& Fitriani, A. (2016). Penerapan project based learning terintegrasi STEM untuk meningkatkan literasi sains siswa ditinjau dari gender. Jurnal Inovasi Pendidikan IPA, 2(2), 202-212.

Ali, M., \& Yuniarni, D. (2016). KEMAMPUAN BERHITUNG BERDASARKAN GENDER PADA ANAK USIA 5-6 TAHUN DI TK MUJAHIDIN 1 PONTIANAK. Jurnal Pendidikan Dan Pembelajaran Khatulistiwa, 5(5).

Aziz, R., \&Mangestuti, R. (2006). Tiga Jenis Kecerdasan Dan Agresivitas Mahasiswa.Jurnal. Universitas Islam Negeri Malang.

Barnas, S., \& Ridwan, I. M. (2019). Perbedaan Gender dalam Pengetahuan, Sikap dan Perilaku Mahasiswa Pendidikan Fisika. DIFFRACTION, 1(2), 34-41.

Brewer, Jo A. 2007 Early Childhood Education, Preschool Throught Primary Grades Sixth Edition, Boston : Pearson

Febrialismanto \& Novianti, R. (2020). Journal of Educational Sciences, 4(2), 404-413.

Febrialismanto \& Hidayatun. (2019). Kemampuan Guru Menggunakan TIK Untuk Pengembangan di, 2(2), 101-111.

Nugraha, A. 2005.Pengembangan Pembelajaran Sains Pada Anak Usia Dini.Jakarta.

Pamuji, N. S., \& Sodikin, S. (2020). Hubungan Jenis Kelamin, Usia, dan Urutan Kelahiran dengan Kemampuan Mengkombinasikan Warna Menggunakan Media Finger Painting. Jurnal Keperawatan Muhammadiyah.

Trundle, C. (2005). Teaching Science During the Early Childhood Years, 2004-2007.

Kristi, L. P. (2013). Perbedaan Gender Terhadap Kemampuan Berhitung Matematika Menggunakan Otak Kanan Pada Siswa Kelas 1. Jurnal IAIN Walisungo Semarang.

Meisa Dwi Anjarsari \& Purwanto. 2013. Meningkatkan Hasil Belajar Materi Mengidentifikasi

Sifat-sifat Bangun Datar. JPGSD . 01 (2): 0-216

Novan Ardy Wiyani. 2014.Psikologi Perkembangan Anak Usia Dini. Gramedia. Yogyakarta.

Novia Kartika Dewi. 2019. Peningkatan Kemampuan Mengenal Bentuk Geometri Melalui Media Jepit Geometri Padakelompok Ataman Kanak-Kanak Bahana Al-Aqsha Di Sidomukti Kecamatan Krian Kabupaten Sidoarjo.Jurnal. www. http://uinsby.ac.id (Diakses 24 Agustus 2020)

Novi Mulyani. 2016. Dasar-Dasar Pendidikan Anak Usia Dini. Yogyakarta. Kalimedia 
Peraturan Daerah Kabupaten Rokan Hilir Nomor 02 Tahun 2017 rpjmd Kabupaten Rokan Hilir 2016-2021

Pitadjeng. 2006. Pembelajaran Matematika yang Menyenangkan. Jakarta: Departemen Pendidikan Nasional, Departemen Pendidikan Nasional. Direktorat Jenderal Pendidikan Tinggi.

Rahmadini, D. A., Novianti, R., \& Solfiah, Y. 2019 Pengaruh Permainan Block Puzzle edukatif Terhadap Kemampuan Mengenal Bentuk Geometri Anak Usia 5-6 Tahun Di Ra AlHidayah Kota Pekanbaru. Jurnal Online Mahasiswa (JOM) Bidang Keguruan Dan Ilmu Pendidikan, 6(1), 1-13.

Rika Elok Rahayu. 2016. Mengembangkan Kemampuan Mengenal Bentuk geometri Melalui Permainan Melompat Bentuk dikelompok A TK Dharma Wanita I Panggung Duwet Kademangan Blitar.Jurnal www. http://simki.unpkediri.ac.id (Diakses 24 Agustus 2020)

Rita Eka Izzaty, Siti Partini Suardiman, Yulia Ayriza, Purwandari, Hiryanto, \& Rosita E. Kusmaryani. 2008. Perkembangan Peserta Didik. Yogyakarta: UNY Press.

Sari, W., Chairilsyah, D., \& Solfiah, Y. 2019. Pengaruh Permainan Kotak Pos Terhadapkemampuan Mengenal Bentuk-Bentuk Geometri Pada Anak Usia 5-6 Tahun Di TK Al-Ittihad Kecamatan Rumbai Pesisir Kota Pekanbaru. Jurnal Online Mahasiswa (JOM) Bidang Keguruan Dan Ilmu Pendidikan, 6(1), 1-15

Slamet Suyanto. 2005. Dasar-dasar Pendidikan Anak Usia Dini. Yogyakarta: Hikayat.

Sri Subarinah. 2006. Inovasi Pembelajaran Matematika. Depdiknas

Sugiyono. 2014. Metode Penelitian Admmistrasi. Albabet. Bandura

Suharsimi Arikunto. 2010. Prosedur penelitian. Jakarta. Rineka Cipta

Trisnawati Tri Sinta. 2017. Pengembangan Kecernasan Kognitif Anak Melalui Permainan Geometri Di Tk Islam Mutiara Way Kandis Bandar Lampung. . Jurnal. www.http://eprints.uny.ac.id (Diakses 20 Januari 2020) 